\section{SUJETOS, INSTITUCIONES Y DERECHOS EN LA IMPLEMENTACIÓN \\ DE LA LEY DE ACCIDENTES \\ DEL TRABAJO EN LA CIUDAD \\ DE BUENOS AIRES (1915-1922)}

\author{
SUBJECTS, INSTITUTIONS AND RIGHTS \\ IN THE IMPLEMENTATION OF THE LAW \\ OF WORK ACCIDENTS IN THE CITY OF \\ BUENOS AIRES (1915-1922) \\ LUDMILA SCHEINKMAN •
}

Ludmila Scheinkman es becaria doctoral del CONICET en el Instituto Interdisciplinario de Estudios de Género de la Facultad de Filosofía y Letras de

\section{Resumen}

Este trabajo aborda los años iniciales de implementación de la Ley de Accidentes del Trabajo en la ciudad de Buenos Aires (1915-1922). Se analiza en primer lugar, la peculiar interacción, diálogos y cruces entre el Departamento Nacional del Trabajo y el Departamento Nacional de Higiene -instituciones intervinientes en la aplicación de la ley-, a través de dos de sus voceros destacados: Alejandro Unsain y Augusto Bunge. Luego avanzamos en el análisis de juicios laborales por accidentes, deteniéndonos en las múltiples acciones emprendidas para obtener resarcimiento; como así también en las ideas de derecho y justicia que las guiaron. A partir de este análisis, sostenemos que las acciones judiciales y extra-judiciales emprendidas por los trabajadores tuvieron un papel central en la construcción práctica de la legislación, sirviendo de sustento a las críticas y propuestas de reformas que llevaron a la modificación de la legislación. la Universidad de Buenos Aires y docente de la Universidad de Buenos Aires.

email: ludsch@gmail.com

\section{Summary}

This work approaches the early years of implementation of the Law on Work Accidents in the city of Buenos Aires (1915-1922). It first analyzes the peculiar interactions, dialogues and clashes between the National Department of Labor and the National Department of Hygiene -institutions involved in the implementation of the law-, through two of its prominent spokesmen: Alejandro Unsain and Augusto Bunge. It then focuses on the scrutiny of labor lawsuits on work accidents, emphasizing the multiple actions undertaken for obtaining compensation; as well as the ideas of law and justice that guided them. Based on this analysis, we argue that judicial and extrajudicial actions undertaken by workers played a central role in the practical realization of the law, serving as the basis for criticisms and proposals for reforms, that lead to its amendment. 